Research paper

\title{
Identification of HSP90 as a new GABARAPL1 (GEC1)-interacting protein
}

\author{
Stéphanie Seguin-Py a, Géraldine Lucchi ${ }^{\mathrm{b}}$, Sophie Croizier ${ }^{\mathrm{a}}$, Fatima Z. Chakrama ${ }^{\mathrm{a}}$, Gilles Despouy ${ }^{\mathrm{a}}$, \\ Jaclyn N. Le Grand ${ }^{a}$, Patrick Ducoroy ${ }^{b}$, Wilfrid Boireau ${ }^{c}$, Michaël Boyer-Guittaut ${ }^{a}$, Michèle Jouvenot ${ }^{a}$, \\ Annick Fraichard ${ }^{a}$, Régis Delage-Mourroux ${ }^{\mathrm{a}, *}$
}

a Université de Franche-Comté, EA3922 «Estrogènes, Expression Génique et Pathologies du Système Nerveux Central », IFR133, U.F.R. Sciences et Techniques, 16 route de Gray, 25030 Besançon Cedex, France

${ }^{\mathrm{b}}$ CLIPP (CLinical Innovation Proteomic Platform), IFR100, Centre Hospitalier Universitaire de Dijon, Université de Bourgogne 1 rue du professeur Marion, 21000 Dijon, France

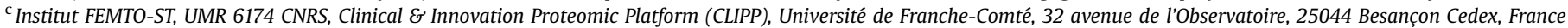

\section{A R T I C L E I N F O}

\section{Article history:}

Received 25 May 2011

Accepted 10 November 2011

Available online 20 November 2011

\section{Keywords:}

17-N-Allylamino-17-

demethoxygeldanamycin (17-AAG):GABA receptor-protein-like 1 (GABARAPL1)

Glandular epithelial cell 1 (GEC1)

Heat shock protein 90 (HSP90)

Michigan cancer foundation-7 (MCF-7)

Proteasome inhibitors

\begin{abstract}
A B S T R A C T
GABARAPL1 belongs to the small family of GABARAP proteins (including GABARAP, GABARAPL1 and GABARAPL2/GATE-16), one of the two subfamilies of the yeast Atg8 orthologue. GABARAPL1 is involved in the intracellular transport of receptors, via an interaction with tubulin and $G_{A B A_{A}}$ or kappa opioid receptors, and also participates in autophagy and cell proliferation. In the present study, we identify the HSP90 protein as a novel interaction partner for GABARAPL1 using GST pull-down, mass spectrometry and coimmunoprecipitation experiments. GABARAPL1 and HSP90 partially colocalize in MCF-7 breast cancer cells overexpressed Dsred-GABARAPL1 and in rat brain. Moreover, treatment of MCF-7 cells overexpressed FLAG-GABARAPL1-6HIS with the HSP90 inhibitor 17-AAG promotes the GABARAPL1 degradation, a process that is blocked by proteasome inhibitors such as MG132, bortezomib and lactacystin. Accordingly, we demonstrate that HSP90 interacts and protects GABARAPL1 from its degradation by the proteasome.
\end{abstract}

(C) 2011 Elsevier Masson SAS. All rights reserved.

\section{Introduction}

The gabarapl1 (gabarap like-1) gene was originally discovered in our laboratory as an early estrogen-regulated gene in guinea pig endometrial glandular epithelial cells (GEC) and was therefore previously named gec1 [1,2].

The GABARAPL1 protein is composed of 117 amino acids, which are highly conserved between species, and belongs to a small family of proteins, called the GABARAP family, based on sequence

Abbreviations: 17-AAG, 17-N-Allylamino-17-demethoxygeldanamycin; $\mathrm{GABA}_{\mathrm{A}}$, $\gamma$-aminobutyric acid, type $A ; G_{A B A} R, \gamma$-aminobutyric acid, type $A$ receptor; GABARAP, $G_{A B A}$ receptor-associated protein; GABARAPL1, GABARAPL2, GABA receptor-protein-like 1 and 2; GATE-16, golgi-associated ATPase enhancer of $16 \mathrm{kDa}$; GEC1, glandular epithelial cell protein 1; GFP, green fluorescent protein; GST, gluthathione-S-transferase; HEK293, human embryonic kidney 293; HSP90, heat shock protein 90; IPTG, isopropyl- $\beta$-D-thiogalactopyranoside; KOR, kappa opioid receptor; MAP-LC3, microtubule-associated protein light chain 3; MCF-7, Michigan cancer foundation-7; NBR1, neighbour of BRCA1; Nix1/BNIP3L, BNIP3 like protein (BNIP3: Bcl2/E1B 19 kDa-interacting protein 3-like protein); NP-40, nonidet-P40; NSF, N-ethylmaleimide sensitive factor; RIP1, receptor interacting protein 1; UTR, untranslated region.

* Corresponding author. Tel.: +33 3816666 24; fax: +33 381666970 .

E-mail address: regis.delage-mourroux@univ-fcomte.fr (R. Delage-Mourroux). identity between the different members. In addition to GABARAPL1, this family also includes GABARAP $\left(\mathrm{GABA}_{\mathrm{A}}\right.$ receptor-associated protein), and GABARAPL2/GATE-16 (GABARAP like-2 protein/ Golgi-associated ATPase enhancer of $16 \mathrm{kDa}$ ), which share $87 \%$ and $61 \%$ identity with GABARAPL1, respectively [3,4]. GABARAPL1 also presents a rather low homology with the MAP-LC3B (microtubuleassociated protein light chain 3B) protein [5].

Very few studies regarding the expression of this protein have been conducted because of its strong identity with GABARAP. Indeed, the existence of an antibody that can discriminate between these two proteins has not yet been proven. The tissue specific expression of the gabarapl1 mRNA, obtained with the use of a probe designed against a unique portion of the 3' UTR, however, reveals that gabarapl1 is ubiquitously expressed with the highest expression levels observed in the brain. Gabarapl1 mRNA is, in fact, the most strongly expressed amongst its closest counterparts in multiple rat brain areas ranging from the olfactory bulb to the brainstem and cerebellum, as well as in the spinal cord. In these structures, gabarapl1 mRNA seems to be localized in neurons and particularly in motoneurons and neuroendocrine neurons [6,7].

The emergence of new GABARAPL1 protein partners has allowed us to hypothesize the role of this small protein in major cellular processes. GABARAPL1 has been shown to interact in vitro 
with two essential membrane receptors in the brain: $G A B A_{A} R$ (gamma-aminobutyric acid, type A receptor) and KOR (kappa opioid receptor) [8-10]. GABARAPL1 could thus participate in neuronal signal transmission by aiding in the transport of these membrane receptors to the cell surface. Tubulin and NSF (N-ethylmaleimide sensitive factor), two other GABARAPL1 binding partners, may contribute to the intracellular trafficking of the two aforementioned receptors [8-11]. Tubulin is a major cell component of the cytoskeleton, known to aid in the guidance of intracellular trafficking, and NSF is already known to play a role in trafficking of neuronal receptors such as AMPA ( $\alpha$-amino-3hydroxy-5-methyl-4-isoxazolepropionic acid) type glutamate and $\beta$-adrenergic receptors. GABARAPL1, via its interaction with tubulin, is also able to promote tubulin assembly and microtubule bundling [8]. The contribution of GABARAPL1 to intracellular protein transport is not restricted to the brain as demonstrated by its interaction with PX-RICS [Phox-RhoGAP (GTPase-activating protein) involved in the $\beta$-catenin- $\mathrm{N}$-cadherin and NMDA (N-methyl-D-aspartate) receptor signaling], a protein that mediates the transport of the $\mathrm{N}$ cadherin/ $\beta$-catenin complex from the ER to the Golgi apparatus in HeLa cells [12].

Due to the high homology between the different members of the GABARAP family, all GABARAPL1 partners outlined above also interact with one or several of the GABARAP family members. Two proteins, namely alpha-synuclein and ARH (Autosomal Recessive Hypercholesterolemia) have been described to interact only with the GABARAPL1 protein but their association with other GABARAP family members has not yet been addressed $[13,14]$.

Some studies have reported a low expression of gabarapl1 mRNA in different types of cancers and we recently demonstrated, from the study of a cohort of 265 breast adenocarcinoma biopsies, that patients with a high expression of gabarapl1 mRNA present a lower risk of recurrence $[15,16]$.

Recently, we also described GABARAPL1 as a new marker of autophagosomes. More precisely, we demonstrated that GABARAPL1 is cleaved in the cells to produce its mature form, is linked onto phospholipids and associates with autophagic vesicles [17,18]. Moreover, it has been suggested that GABARAPL1 plays a role in selective autophagy, a form of autophagy that targets specific proteins or organelles to be degraded in the lysosomes, due to its association with p62/SQSTM1 (Sequestosome 1), NBR1 (Neighbour of Brca1 gene) and Nix1/BNIP3L [BNIP3 like protein (BNIP3: Bcl2/ E1B $19 \mathrm{kDa}$-interacting protein 3-like protein)], which have all been described as cargo adapters [19-22].

To search for new functions of the GABARAPL1 protein, we looked for new GABARAPL1 partners in rat brain, a tissue that highly expresses gabarapl1, by using a GST pull-down assay coupled to mass spectrometry. We report here an interaction between GABARAPL1 and the molecular chaperone HSP90 in rat brain and in MCF-7 cells. In cells, a specific inhibition of HSP90 ATPase activity by 17-AAG (17$\mathrm{N}$-Allylamino-17-demethoxygeldanamycin) disrupts this interaction whereas the use of the potent proteasome inhibitor MG132 (ZLeu-Leu-Leu-al) protects GABARAPL1 from degradation. GABARAPL1 can consequently now be defined as a new HSP90 client protein.

\section{Materials and methods}

\subsection{Animals and tissue preparation}

All animal use and care protocols were in accordance with institutional guidelines (all protocols were approved and investigators authorized). Sprague-Dawley rats were obtained from Charles River Laboratories (L'Arbresle, France).
Rats were anesthetized with an intraperitoneal injection of chloral hydrate $7 \%(1 \mathrm{ml} / 200 \mathrm{~g})$, and then perfused as previously described [23] with $0.9 \%(\mathrm{w} / \mathrm{v}) \mathrm{NaCl}$ followed by ice-cold $1 \%(\mathrm{w} / \mathrm{v})$ paraformaldehyde fixative in $0.1 \mathrm{M}$ phosphate buffer. The brains were removed, post-fixed in the same fixative overnight at $4{ }^{\circ} \mathrm{C}$, immersed overnight in a $15 \%(\mathrm{w} / \mathrm{v})$ sucrose solution at $4{ }^{\circ} \mathrm{C}$, and then frozen over liquid nitrogen. Brains were serially cut into $10 \mu \mathrm{m}$ coronal sections on a cryostat-microtome, mounted on gelatinated slides and stored at $-40{ }^{\circ} \mathrm{C}$ until further analysis.

\subsection{Reagents and antibodies}

Cell culture reagents were purchased from Invitrogen (Carlsbad, CA). The following antibodies were used: two different polyclonal anti-GABARAPL1 antibodies, one from Chemicon Millipore (AB15278) for Western blotting experiments and one from Protein Tech Group (11010-1-AP) for immunohistochemistry and immunoprecipitation experiments, polyclonal anti-GFP (Chemicon Millipore, AB3080), monoclonal anti-HSP90 (TebuBio, AC88), monoclonal anti-FLAG M2 (Sigma-Aldrich, A2220), monoclonal anti-RIP1 (receptor interacting protein 1) (BD Pharmingen, 551041), monoclonal anti-tubulin (Abcam, ab56676) and polyclonal antiactin (Sigma, A5060). MG132 (Z-Leu-Leu-Leu-al) (Sigma-Aldrich, C2211), bortezomib (Santa Cruz Biotechnology sc-217785), lactacystin (Santa Cruz Biotechnology, sc-3575) and 17-(Allylamino)-17demethoxygeldanamycin (17-AAG) (Sigma-Aldrich, A8476) were prepared in DMSO. The human recombinant HSP90 $\beta$ protein was purchased from Cayman Chemical (10342).

\subsection{Plasmids}

The pGEX-4T-2, pGEX-4-T2 GST-GABARAPL1 and pGEX-4-T2 GST-GABARAPL1 (22-117) vectors expressing the glutathione Stransferase (GST) enzyme, the GST-GABARAPL1 and the GSTGABARAPL1 (22-117) proteins were described previously [8]. The gabarapl1 coding sequence flanked by two tag sequences, coding for a Flag peptide and a six-histidine tail, respectively, was cloned into the XbaI and BamH1:BglII sites of the pSBet vector [24], allowing expression of the FLAG-GABARAPL1-6HIS protein in Escherichia coli bacteria. The pGST-HSP90 $\alpha$ and the pGFP-HSP90 $\beta$ vectors were kindly provided by Dr. Altieri (University of Massachusetts Medical School, Worcester, USA) and Dr. J. Kim (Korea University, Seoul, South Korea), respectively.

\subsection{Cell culture and transfection}

The HEK293 (Human Embryonic Kidney 293) (ATCC, CRL-1573) and MCF-7 (Michigan Cancer Foundation) (ATCC, HTB-22) cells were cultured in DMEM (Dulbecco's Minimum Essential Medium, Invitrogen, 11880) supplemented with $2 \mathrm{mM}$ L-Glutamine (Invitrogen, 25030-032), $100 \mu \mathrm{g} / \mathrm{ml}$ penicillin, $100 \mu \mathrm{g} / \mathrm{ml}$ streptomycin (Invitrogen, 15140) and 10\% (for the HEK293 cells) or 5\% (for the MCF-7 cells) foetal bovine serum (FBS, Invitrogen, 10270-106) and kept in a $5 \% \mathrm{CO}_{2}$ incubator at $37{ }^{\circ} \mathrm{C}$. The MCF-7-FLAG-GABARAPL16HIS and MCF-7-Dsred-GABARAPL1 cell lines were previously created [17]. These cell lines were maintained in complete medium supplemented with $100 \mu \mathrm{g} / \mathrm{ml}$ Hygromycin B (PAA, P02-015) and $100 \mu \mathrm{g} / \mathrm{ml}$ G418 (PAA, P02-012), respectively. TransFast reagent (Promega, E2431) was used to transiently transfect HEK293 cells plated in $10 \mathrm{~cm}$-diameter culture dishes $\left(5 \times 10^{6}\right.$ cells per Petridish) and Jet Prime reagent (Polyplus Transfection, 114-07) was used to transiently transfect MCF-7-Dsred-GABARAPL1 cells plated in 24 -well plates $\left(5 \times 10^{4}\right.$ cells per well), according to the manufacturer's recommendations. Ten $\mu \mathrm{g}$ or $500 \mathrm{ng}$ of pGFP-HSP90 $\beta$ 
vector were used to transfect HEK293 and MCF-7 Dsred-GABARARAPL1 cells, respectively.

MCF-7-FLAG-GABARAPL1-6HIS cells plated in 6-well plates $\left(4 \times 10^{5}\right.$ cells per well) or MCF-7-Dsred-GABARAPL1 cells plated in 24 -well plates cultured on glass coverslips $\left(5 \times 10^{4}\right.$ cells per well) were treated overnight with $1 \mu \mathrm{M}$ of $17-\mathrm{AAG}$ in complete medium for the inhibition of HSP90 activity in the presence or in the absence of $2 \mu \mathrm{M}$ MG132, $5 \mu \mathrm{M}$ lactacystin or $25 \mathrm{nM}$ bortezomib for the inhibition of proteasome activity. Kinetics (17AAG, MG132) and dose effects (MG132, lactacystin, bortezomib) were conducted to test the efficiency of these different compounds. Total proteins extracts from 6-well plates were used for immunoblotting. Cells cultured in 24-well plates were analysed by confocal microscopy.

\subsection{Expression, production and purification of fusion proteins}

The pGST-HSP90 $\alpha$ vector, the pGEX-4-T2 GST-GABARAPL1, the pGEX-4-T2 GST-GABARAPL1 (22-117), the pGEX-4-T2 GSTGABARAP and the pGEX-4-T2 GST-GATE-16 vectors were used to transform BL21-DE3 E.coli. The different fusion proteins expressed from these vectors were induced with $0.5 \mathrm{mM}$ isopropyl- $\beta$-D-thiogalactopyranoside (IPTG) for $2 \mathrm{~h}$. The bacterial pellet, obtained by centrifugation $\left(5000 \mathrm{~g}, 10 \mathrm{~min}, 4^{\circ} \mathrm{C}\right)$, was resuspended in $800 \mu \mathrm{l}$ of PBS (0.137 M NaCl, $3.3 \mathrm{mM} \mathrm{KCl,} 10 \mathrm{mM} \mathrm{Na}_{2} \mathrm{HPO}_{4}, 1.8 \mathrm{mM} \mathrm{KH}_{2} \mathrm{PO}_{4}$ ) supplemented with $1 \%(\mathrm{v} / \mathrm{v})$ Triton $\mathrm{X}-100,1 \mathrm{mM}$ protease inhibitors (Sigma-Aldrich P8340) and $0.2 \mathrm{mM}$ phenylmethylsulfonyl fluoride (PMSF). After sonication (Sonics and Materials) (3 times for $15 \mathrm{~s}$ ), a second centrifugation ( $10000 \mathrm{~g}, 20 \mathrm{~min}, 4^{\circ} \mathrm{C}$ ) was performed to clear the lysate. The GST-fusion proteins contained in the supernatant were bound to $100 \mu \mathrm{l}$ of glutathione-agarose beads (Sigma-Aldrich, G4510) for $2 \mathrm{~h}$ at $4{ }^{\circ} \mathrm{C}$ under agitation. The beads were then washed 3 times in PBS supplemented with $500 \mathrm{mM} \mathrm{NaCl}$.

The FLAG-GABARAPL1-6HIS protein was purified using a Ni-NTA Purification System (Qiagen 30210) according to the manufacturer's instructions. After induction of the pool of the proteins with IPTG, bacterial cells were incubated in lysis buffer $(20 \mathrm{mM}$ Tris- $\mathrm{HCl}, 20 \%$ (v/v) glycerol, $0.2 \mathrm{mM}$ EDTA, $500 \mathrm{mM} \mathrm{KCl}, 10 \mathrm{mM}$ imidazole, $10 \mathrm{mM}$ $\beta$-mercaptoethanol, $1 \mathrm{mg} / \mathrm{ml}$ lysozyme) for $30 \mathrm{~min}$ on ice. After sonication ( 3 times for $15 \mathrm{~s}$ ) and centrifugation (16 $000 \mathrm{~g}, 30 \mathrm{~min}$, $4{ }^{\circ} \mathrm{C}$ ), the cleared lysate was incubated with Ni-NTA resin for $2 \mathrm{~h}$ at $4{ }^{\circ} \mathrm{C}$. After centrifugation $\left(5000 \mathrm{~g}, 5 \mathrm{~min}, 4^{\circ} \mathrm{C}\right)$, the resin was washed 3 times in a wash buffer [ $20 \mathrm{mM}$ Tris- $\mathrm{HCl}, 20 \%(\mathrm{v} / \mathrm{v})$ glycerol, $0.2 \mathrm{mM}$ EDTA, $100 \mathrm{mM} \mathrm{KCl}, 20 \mathrm{mM}$ imidazole, $10 \mathrm{mM} \beta$ mercaptoethanol, $0.5 \mathrm{mM}$ PMSF]. The FLAG-GABARAPL1-6HIS protein was then eluted with increasing concentrations of imidazole (50-250 mM).

\subsection{GST pull-down affinity}

Total protein lysates from HEK293 cells transiently transfected by the pGFP-HSP90 $\beta$ vector or from rat brains (previously cut into small pieces and homogenized with a hand-driven Potter-Elvehjem apparatus) were obtained by incubation on ice for $30 \mathrm{~min}$ in GST pull-down lysis buffer [(10 mM Tris- $\mathrm{HCl} \mathrm{pH}$ 7.6, $100 \mathrm{mM} \mathrm{NaCl}$, $5 \mathrm{mM}$ EDTA, $10 \mathrm{mM} \mathrm{MgCl}$, 0.5\% (v/v) NP-40, 1\% (v/v) Triton X100, $1 \mathrm{mM}$ protease inhibitors (Sigma-Aldrich P8340)] followed by centrifugation ( $30 \mathrm{~min}, 16000 \mathrm{~g}, 4^{\circ} \mathrm{C}$ ). Five $\mathrm{mg}$ of rat brain protein extract were incubated with GST or GST-GABARAPL1 (prepared as previously described) bound to $100 \mu$ l of glutathione-agarose beads in GST pull-down lysis buffer overnight at $4{ }^{\circ} \mathrm{C}$ under constant agitation. After three extensive washes in PBS supplemented with $200 \mathrm{mM} \mathrm{NaCl}$, proteins were eluted in $40 \mu \mathrm{l}$ of SDS-PAGE loading buffer (78 mM Tris-HCl, pH 6.8, 2.5\% (w/v) SDS, 12.5\% (v/v) glycerol, 6.25\% (v/v) $\beta$-mercaptoethanol, $0.025 \%(\mathrm{w} / \mathrm{v}$ ) bromophenol blue) and separated on a $10 \%$ or a $12.5 \%$ SDS-PAGE gel. After
Coomassie blue staining, seven protein bands of interest were excised from the gel and analysed by mass spectrometry. To test in vitro binding of GABARAPL1 with HSP90, GST pull-down experiments were performed using GST-HSP90 $\alpha$, GST-GABARAPL1 or GST-GABARAPL1 (22-117) fusion proteins (prepared as previously described) immobilized on $100 \mu$ glutathione-agarose beads in combination with either a rat brain protein extract $(5 \mathrm{mg})$ or a HEK293 expressing GFP-HSP90 $\beta$ cell lysate $(1 \mathrm{mg})$ or a purified FLAG-GABARAPL1-6HIS protein (500 ng), or a human recombinant HSP90 $\beta$ protein $(5 \mu \mathrm{g})$.

\subsection{Mass spectrometry analysis}

Bands of interest were excised manually from the SDS-PAGE gel and cut into $1 \mathrm{~mm}^{3}$ pieces. The gel fragments were then washed in $0.1 \mathrm{M}$ ammonium bicarbonate $\left(\mathrm{NH}_{4} \mathrm{HCO}_{3}\right)$ for $10 \mathrm{~min}$ and dehydrated in acetonitrile for 10 min. Dried pieces of bands were incubated in the dark successively in $10 \mathrm{mM}$ tris (2-carboxyethyl) phosphine (TCEP)/0.1 $\mathrm{M}\left(\mathrm{NH}_{4} \mathrm{HCO}_{3}\right)\left(30\right.$ min at $\left.37^{\circ} \mathrm{C}\right)$, acetonitrile (8 min), $55 \mathrm{mM}$ iodoacetamide/0.1 $\mathrm{M} \mathrm{NH}_{4} \mathrm{HCO}_{3}(20 \mathrm{~min}), 0.1 \mathrm{M}$ $\mathrm{NH}_{4} \mathrm{HCO}_{3}(2 \mathrm{~min})$ and acetonitrile $(8 \mathrm{~min})$. Each piece of band was then digested by $20 \mu \mathrm{l}$ of a digestion solution ( $10 \mathrm{ng} / \mu \mathrm{l}$ of trypsin in $40 \mathrm{mM} \mathrm{NH} \mathrm{HCO}_{3}$ and 10\% (v/v) acetonitrile (Trypsin Gold Mass Spectrometry Grade, PROMEGA, V5280)) for $30 \mathrm{~min}$ at $4{ }^{\circ} \mathrm{C}$. Fifteen $\mu \mathrm{l}$ of this solution was subsequently removed and $10 \mu \mathrm{l}$ of $40 \mathrm{mM}$ $\mathrm{NH}_{4} \mathrm{HCO}_{3} / 10 \%(\mathrm{v} / \mathrm{v})$ acetonitrile was added, prior to incubation at $37{ }^{\circ} \mathrm{C}$ for $2 \mathrm{~h}$. Resulting peptides were concentrated on C18 (PerfectPure Eppendorf C18, 0030008 405) according to the manufacturer's instructions. An aliquot $(0.5 \mu \mathrm{l})$ of the concentrate solution was then deposited onto a Ground Steel MALDI target together with $1 \mu \mathrm{l}$ of matrix solution $(3.5 \mathrm{mg} / \mathrm{ml} \alpha$-cyano-4hydroxycinnamic acid in 50\% (v/v) acetonitrile, $0.5 \%(\mathrm{w} / \mathrm{v})$ trifluoroacetic acid). Peptides were analysed by MS and MS/MS with a MALDI-TOF/TOF UltraFlex II (Bruker Daltonics, Bremen, Germany) mass spectrometer. Proteins were identified by comparison to the rat MSDB (Mass Spectrometry protein sequence DataBase) databank.

\subsection{Immunoprecipitation}

Total protein lysates from MCF-7 cells or rat brains (previously cut into small pieces and homogenized with a hand-driven PotterElvehjem apparatus) were obtained by incubation on ice for $30 \mathrm{~min}$ in immunoprecipitation buffer [50 mM HEPES, pH 7.6, $150 \mathrm{mM}$ $\mathrm{NaCl}, 5 \mathrm{mM}$ EDTA, 0.1\% (v/v) NP-40, $1 \mathrm{mM}$ protease inhibitors (Sigma-Aldrich P8340)] followed by a centrifugation (30 min, $16000 \mathrm{~g}, 4^{\circ} \mathrm{C}$ ). The supernatants were then incubated with $30 \mu \mathrm{l}$ of magnetic beads (Dynabeads Protein G Invitrogen, 100-03D) together with $2 \mu \mathrm{g}$ of the indicated antibody [anti-FLAG M2 (SigmaAldrich) or anti-GABARAPL1 (Protein Tech Group)] under constant agitation at room temperature for $10 \mathrm{~min}$. MCF-7-FLAG-GABARAPL1-6HIS cell lysate $(100 \mu \mathrm{g})$ or rat brain extract $(500 \mu \mathrm{g})$ were then added to the beads and incubated for $30 \mathrm{~min}$ at room temperature while agitating. After three washes in PBS, immunocomplexes were eluted in 2X SDS loading buffer and loaded on a $12.5 \%$ SDS-PAGE gel. The target proteins were then detected by immunoblotting as described below.

\subsection{Western blot analysis}

Whole cell lysates $(40 \mu \mathrm{g})$ were separated by SDS-PAGE on a $10 \%$, $12.5 \%$ or a $15 \%$ gel before transfer to an Immobilon-P PVDF membrane (Dutscher, 44088). The membranes were blocked with $5 \%$ (w/v) skim milk in 0.1\% Tween 20/TBS (10 mM Tris- $\mathrm{HCl}, \mathrm{pH} 7.4$, $150 \mathrm{mM} \mathrm{NaCl}, 0.1 \%(\mathrm{v} / \mathrm{v})$ Tween 20$)$ and incubated at $4{ }^{\circ} \mathrm{C}$ overnight 
with primary antibodies in antibody block buffer $(0.5 \%(\mathrm{w} / \mathrm{v})$ skim milk in $0.1 \%(\mathrm{v} / \mathrm{v})$ Tween 20/TBS). The following antibodies were used at the indicated dilution: polyclonal anti-GABARAPL1 (Chemicon Millipore) (1:2000), polyclonal anti-GABARAPL1 (Protein Tech Group) (1:1000), polyclonal anti-HSP90 $\beta$ (1:3000), monoclonal anti-HSP90 (1:2000), polyclonal anti-GFP (1:5000), monoclonal anti-RIP1 (1:2500), monoclonal anti-tubulin $(1: 10000)$ and polyclonal anti-actin (1:10 000). Immunoreactive bands were detected using goat horseradish peroxydase (HRP)coupled secondary anti-mouse (P.A.R.I.S, BI 2413C) or anti-rabbit (P.A.R.I.S, BI 2407C) antibodies (1:20 000 in antibody block buffer) and ECL Plus reagent (GE Healthcare Life Sciences, RPN2132), according to the manufacturer's protocol.

\subsection{Immunohistochemistry}

Rat brain sections were rinsed in PBS supplemented with $0.3 \%$ (v/v) Triton X100 and incubated overnight with the primary antiGABARAPL1 antibody (1:200) diluted in PBS containing 0.3\% (v/v) Triton X100,1\% (w/v) bovine serum albumine, $10 \%(\mathrm{w} / \mathrm{v})$ skim milk and $0.01 \%(\mathrm{w} / \mathrm{v})$ sodium azide at room temperature. The labeling was then revealed with a secondary goat anti-rabbit IgG conjugated Alexa Fluor-488 (1:800, Invitrogen) for $1 \mathrm{~h}$ at room temperature. Then, sections were incubated, under the same conditions, with the monoclonal anti-HSP90 (1:400) antibody diluted in PBS containing $0.3 \%(\mathrm{v} / \mathrm{v})$ Triton X100 and revealed with a donkey anti-mouse IgG conjugated to Alexa Fluor-555 (1:800, Invitrogen). Fluorescent sections were then observed using a confocal microscope described below.

\subsection{Confocal microscopy analysis}

Cells grown on coverslips were fixed in PBS-paraformaldehyde 4\% (w/v) (PFA, Sigma-Aldrich, P6148) for $15 \mathrm{~min}$ and washed once with PBS. Cells and labeled brain sections were then analysed using a fluorescence laser scanning confocal microscope Fluoview FV1000 BX (Olympus, France). Images were obtained through a DP 75 numeric camera using the Fluoview FV1000 software (Olympus, France).

\section{Results}

\subsection{Identification of new GABARAPL1-interacting partners}

In order to further understand the biological functions of GABARAPL1, we searched for new interacting partners of this protein using rat brain protein extracts in a GST pull-down experiment coupled to mass spectrometry. Proteins eluted from the GST pull-down experiments were separated by SDS-PAGE and visualized by Coomassie staining. Many proteins displayed a specific interaction with GST-GABARAPL1 (Fig. 1D). Seven intensive bands not present or of lower intensity in the control tracks [corresponding to GST alone (Fig. 1A), GST incubated with rat brain extract (Fig. 1B) and GST-GABARAPL1 alone (Fig. 1C)] were excised from the gel and analysed by mass spectrometry. Of the various potential GABARAPL1 protein partners identified, eleven were confirmed by both MS and MS/MS analysis (Table 1). Among all identified proteins, we recovered tubulin, a protein already known to interact in vitro with GABARAPL1 [8] and clathrin heavy chain, a protein described to associate with GABARAP [25]. The HSP90 $\beta$ protein corresponding to the $84 \mathrm{kDa}$ heat shock protein (Q1PSW2) identified in band $\mathrm{n}^{\circ} 4$ (Fig. 1D) by both MS (Mascot score: 63 ) and MS/MS (two peptides with respectively a Mascot score of 63 and 61) was particularly interesting due to its implication in numerous cellular processes such as protein folding, stress response, signal
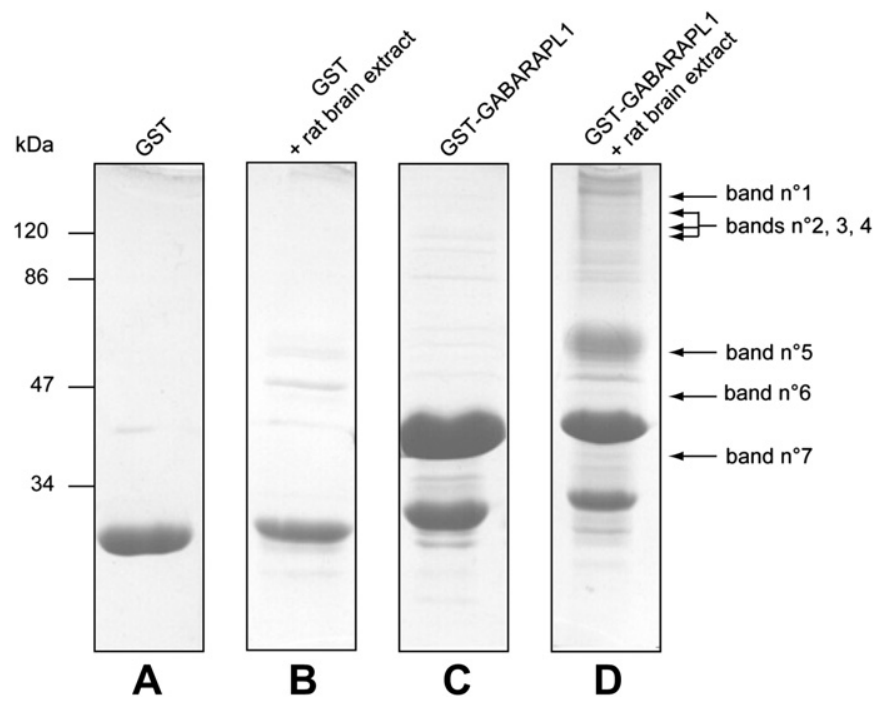

Fig. 1. Identification of new GABARAPL1-interacting proteins by GST pull-down assay coupled to mass spectrometry. GST (A, B) and GST-GABARAPL1 (C, D) were expressed in E.coli and purified by glutathione-agarose affinity chromatography prior to incubation with rat brain protein extracts (B, D). After extensive washing, bound material was resolved by SDS-PAGE (10\%) and analyzed by Coomassie staining. Several proteins specifically bound GABARAPL1 and seven bands were excised from the gel to undergo tryptic digestion and mass spectrometry analysis (Table 1 ).

transduction and tumor progression [26-28]. In the rat central nervous system (CNS), HSP90 is markedly expressed throughout all neuronal subpopulations suggesting its functional role in the CNS [29]. Moreover, a recent global analysis of the human autophagic gene network has identified new GABARAPL1 protein partners including the HSP90 protein in HEK293 cells using immunoprecipitation coupled to mass spectrometry [30].

\subsection{GABARAPL1 interacts with HSP90}

\subsubsection{GST pull-down experiments}

A variety of GST pull-down experiments using GST and different GST-fusion proteins [GST-HSP90 $\alpha$, GST-GABARAPL1, GST-GABARAPL1 (22-117)] were used to confirm the interaction between GABARAPL1 and both HSP90 $\alpha$ and $\beta$ isoforms. A GST pull-down assay using recombinant bacterial GST-GABARAPL1 and rat brain protein extracts coupled to Western blot analysis confirmed the in vitro interaction of this protein with HSP90 (Fig. 2A). A GST pulldown assay followed by Western blot analysis using an anti-GFP antibody also demonstrated an interaction between these two proteins in HEK293 cells transiently expressing GFP-HSP90 $\beta$ (Fig. 2B).

Two different GST pull-down experiments utilizing either GSTGABARAPL1 and the human recombinant HSP90 $\beta$ protein or GSTHSP90 $\alpha$ and the purified FLAG-GABARAPL1-6HIS protein demonstrated the direct interaction between GABARAPL1 and HSP90 $\alpha$ or HSP90 $\beta$ (Fig. 2C, D).

Mansuy and colleagues have demonstrated, using a deletion mutant of GABARAPL1 in a GST pull-down experiment, that the 22 amino-terminal residues of GABARAPL1 are necessary for tubulin binding [8]. In order to determine if this region of GABARAPL1 is also responsible for its interaction with $\mathrm{HSP} 90 \beta$, we subsequently tested the ability of this deletion mutant to interact with HSP90 $\beta$ in a pull-down assay performed with HEK293 GFP-HSP90 $\beta$ cell lysates and with the human recombinant HSP90 $\beta$ protein. The intensity of the signals corresponding to GFP-HSP90 $\beta$ and HSP90 $\beta$ was strongly reduced when using the deletion mutant compared to the wild- 
Table 1

Mass spectrometry results for the seven bands identified by MALDI-TOF MS and/or MS/MS following GST pull-down experiments performed from total rat brain extract.

\begin{tabular}{|c|c|c|c|c|c|c|c|}
\hline Bands & Protein (accession number) & $\begin{array}{l}\text { Theoretical vs } \\
\text { apparent MW }(\mathrm{kDa})^{\mathrm{a}}\end{array}$ & $\begin{array}{l}\text { Matched peptides } \\
\text { (MS mode) }\end{array}$ & $\begin{array}{l}\text { Percentage of } \\
\text { coverage }\end{array}$ & $\begin{array}{l}\text { Mascot } \\
\text { score }^{\text {b }}\end{array}$ & $\begin{array}{l}m / z \text { of the precursor } \\
\text { ion }(\mathrm{MS} / \mathrm{MS} \text { mode })^{\mathrm{c}}\end{array}$ & $\begin{array}{l}\text { Mascot } \\
\text { score }^{d}\end{array}$ \\
\hline \multirow[t]{2}{*}{1} & Clathrin heavy chain (P11442) & $193.2 / 180$ & 63 & 37.7 & 447 & 1296 & 44 \\
\hline & & & & & & 1942 & 96 \\
\hline 2 & RIM2-5B (Q9JIS1) & $173.2 / 140$ & 35 & 26.5 & 61 & & \\
\hline \multirow[t]{3}{*}{3} & D100 protein (dynamin) (P21575) & $96.2 / 120$ & 25 & 24.5 & 96 & 2093 & 32 \\
\hline & $\mathrm{Na}+/ \mathrm{K}+$ exchanging ATPase alpha-3 chain (P06687) & $113 / 120$ & 14 & 17.6 & 61 & & \\
\hline & AP-2 complex subunit alpha-2 (P18484) & $104.8 / 120$ & 11 & 14.3 & 63 & 1586 & 31 \\
\hline \multirow[t]{3}{*}{4} & $84 \mathrm{kDa}$ heat shock protein (HSP90 $\beta)$ (Q1PSW2) & $83.6 / 110$ & 19 & 30 & 63 & 2255 & 63 \\
\hline & & & & & & 1348 & 61 \\
\hline & Proteasome 26-S subunit non-ATPase 2 (Q4FZT9) & $100.9 / 110$ & 19 & 30.2 & 63 & & \\
\hline \multirow[t]{5}{*}{5} & Tubulin beta-2 (Q6P9T8) & $50.2 / 55$ & 37 & 68.8 & 228 & 1229 & 70 \\
\hline & & & & & & 1620 & 48 \\
\hline & & & & & & 2014 & 69 \\
\hline & Tubulin alpha chain (P68370) & $50.8 / 55$ & 25 & 59.6 & 133 & 1756 & 81 \\
\hline & & & & & & 2415 & 94 \\
\hline 6 & $\begin{array}{l}\text { LanC lantibiotic synthetase component } \\
\text { C-like } 1 \text { (Q9QX69) }\end{array}$ & $46 / 45$ & 10 & 21.6 & 66 & 1359 & 43 \\
\hline \multirow[t]{3}{*}{7} & $\begin{array}{l}\text { Glyceraldehyde-3-phosphate } \\
\text { dehydrogenase (Q9QWU4) }\end{array}$ & $36.1 / 40$ & 18 & 42.6 & 113 & 1779 & 73 \\
\hline & $\begin{array}{l}\text { Guanidine nucleotide binding } \\
\text { protein beta } 2 \text { (P54313) }\end{array}$ & $37.3 / 40$ & & & & 1336 & 57 \\
\hline & Microtubule-associated protein 1B (P15205) & $269.5 / 40$ & - & - & - & 1927 & 52 \\
\hline
\end{tabular}

a The reported theoretical MW is that of the protein in the database MSDB

b In MS mode, a Mascot score above 56 is significant $(p<0.05)$.

c Precursor ions are single-charged unless stated.

d In MS/MS mode, a Mascot score above 30 is significant $(p<0.05)$.

type protein, showing that the amino-terminus of GABARAPL1 largely contributes to the interaction with $\operatorname{HSP90} \beta$ (Fig. 2B, C).

Moreover, a direct interaction between GST-GABARAP or GSTGATE-16 and human recombinant HSP90 $\beta$ protein was also established (Fig. 2E) demonstrating that HSP90 $\beta$ could also have a chaperone effect on other members of the GABARAP family.

\subsubsection{Coimmunoprecipitation experiments}

To confirm this interaction in vivo, we performed an immunoprecipitation experiment using rat brain extracts and an antiGABARAPL1 antibody (Protein Tech Group) or an anti-FLAG M2 antibody (Sigma-Aldrich) followed by Western blotting using antiGABARAPL1 (Chemicon, Millipore) and anti-HSP90 antibodies
A

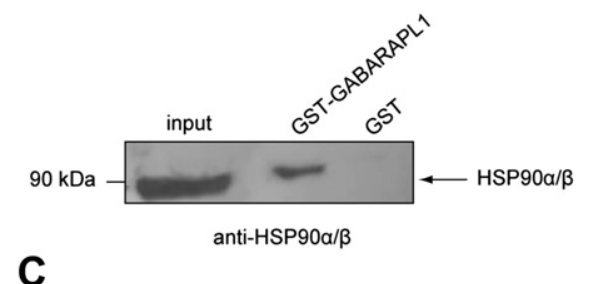

C

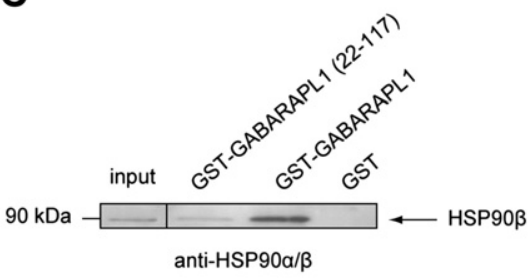

E
B

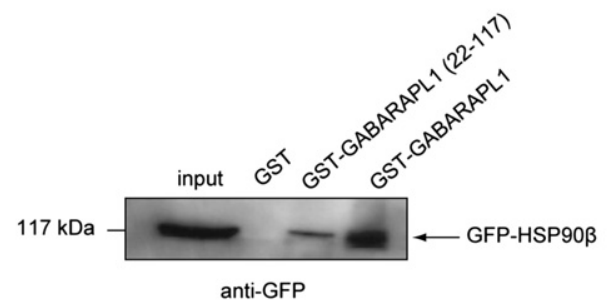

D

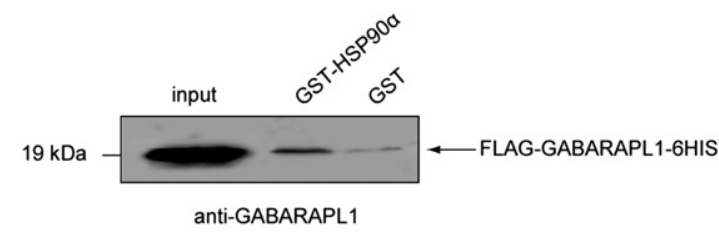

anti-GABARAPL1

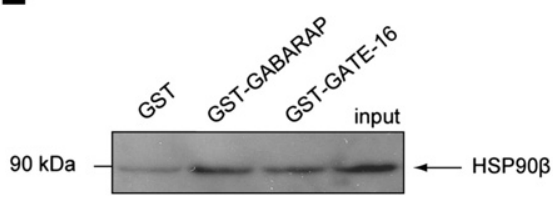

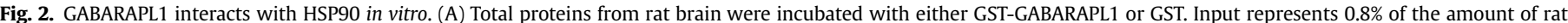

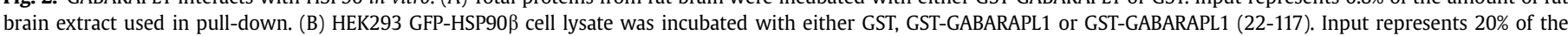

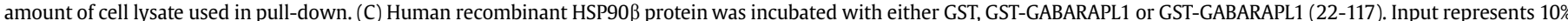

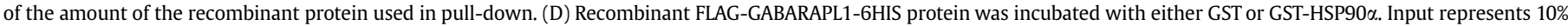

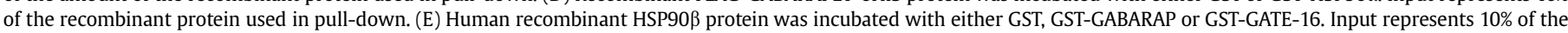

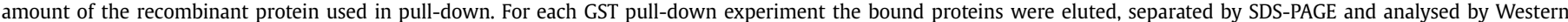

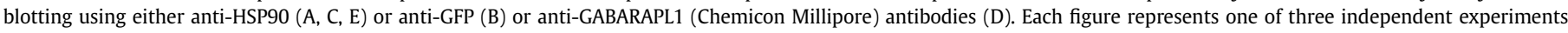
performed with similar results. 
(Fig. 3). The anti-GABARAPL1 antibody from Chemicon cross-reacts with GABARAP and GABARAPL1 while the antibody from Protein Tech Group shows little to no cross-reaction with the GABARAP protein under the conditions used (data not shown). In Fig. 3, we note that the HSP90 protein was coimmunoprecipitated with GABARAPL1, confirming an interaction between HSP90 and GABARAPL1 in rat brain (Fig. 3A) and in MCF-7-FLAG-GABARAPL16HIS cells (Fig. 3B). Three different irrelevant antibodies (antirabbit GFP, anti-rabbit $\operatorname{IgG}$ and anti-mouse $\operatorname{IgG}$ ) were used as immunoprecipitation negative controls. The use of an antiGABARAPL1 antibody (Chemicon, Millipore) that detects both GABARAPL1 and GABARAP for Western blot analysis showed two bands of different intensity in the brain, a higher and more intense band corresponding to GABARAPL1 and the other one corresponding to GABARAP (Fig. 3A). This observation also suggests that GABARAP could interact with HSP90 or that GABARAP was coimmunoprecipitated with GABARAPL1. In MCF-7-FLAG-GABARAPL16HIS cells, however, the GABARAPL1/HSP90 interaction is indubitable given that GABARAP could not be immunoprecipitated by the anti-FLAG antibody (Fig. 3B).

\subsection{GABARAPL1 colocalizes with HSP90}

\subsubsection{Colocalization in MCF-7-Dsred-GABARAPL1 cells}

Following demonstration of an in vitro and an in vivo interaction between GABARAPL1 and HSP90, we investigated the possibility of a colocalization of these two proteins in the MCF-7-DsredGABARAPL1 stable cell line transiently transfected with a plasmid encoding the GFP-HSP90 $\beta$ protein. This stable cell line overexpresses the red fluorescent Dsred-GABARAPL1 fusion protein, which localizes to perinuclear intracytoplasmic vesicles described to be autophagosomes and lysosomes [17]. Following transfection, the GFP-HSP90 $\beta$ protein was widely expressed throughout the cell, mainly in the cytoplasm, but also displayed punctate staining. Amongst these dots, a partial colocalization of GABARAPL1 with GFP-HSP90 $\beta$ was clearly observed (Fig. 4A).

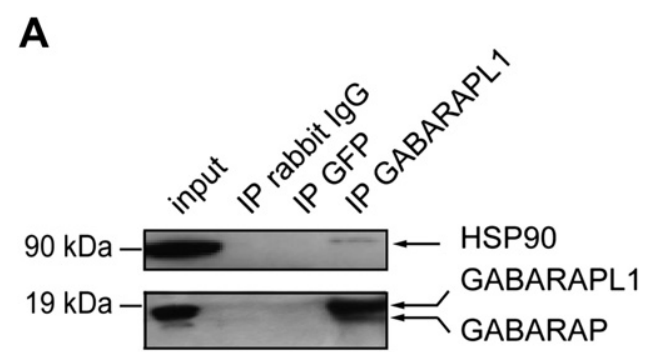

B

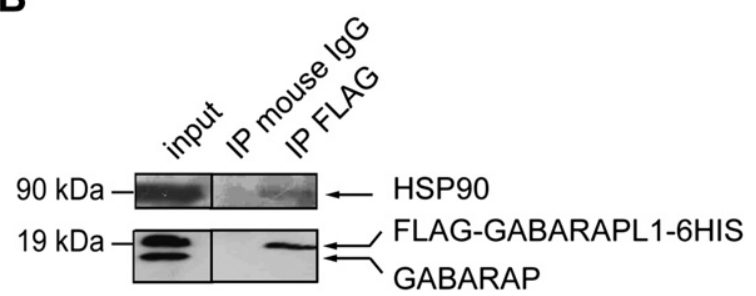

Fig. 3. GABARAPL1 interacts with HSP90 in vivo. Immunodetection of HSP90 and GABARAPL1 (Chemicon antibody) from $500 \mu \mathrm{g}$ of rat brain extract (A) and $100 \mu \mathrm{g}$ of MCF-7-FLAG-GABARAPL1-6HIS cell lysate (B) after GABARAPL1 immunoprecipitation [anti-GABARAPL1 antibody (Protein Tech Group) (A) or anti-FLAG antibody (B)]. Three irrelevant antibodies (IP GFP, IP rabbit IgG or IP mouse IgG) were used. Inputs represent $8 \%$ (A) and $40 \%$ (B) of the amount of cell lysate used in immunoprecipitation. Each figure represents one of three independent experiments performed with similar results.

\subsubsection{Colocalization in rat brain}

To study if this colocalization also occurs in vivo, we performed immunohistochemistry on rat brain sections within the dorsal retrosplenial cortex, substantia nigra and reticular nucleus thalamus using anti-GABARAPL1 (Protein Tech Group) and anti-HSP90 antibodies. The anti-GABARAPL1 antibody has been previously used in immunofluorescence staining to detect GABARAPL1 in HT29 cells [31]. These brain areas were previously described to display a strong expression of gabarapl1 mRNA [6,7]. GABARAPL1 and HSP90 were highly expressed as intracytoplasmic dots and, in agreement with the results obtained in MCF-7-Dsred-GABARAPL1 cells, a partial colocalization was observed. Furthermore, both these proteins also presented a diffuse expression throughout the cytoplasm, where they partially colocalized (Fig. 4B).

\subsection{7-AAG promotes proteasome-dependent degradation of GABARAPL1}

HSP90 is a chaperone for several client proteins involved in transcriptional regulation, signal transduction and cell cycle control $[26,27]$. The HSP90 activity inhibitor 17-AAG, an analogue of geldanamycin, blocks the association of HSP90 with its substrates by disrupting its ATPase function leading to the degradation of these client proteins. The majority of proteins whose stability is regulated by HSP90 are degraded by the proteasome $[32,33]$.

Wild-type MCF-7 cells and MCF-7 cells stably expressing the FLAG-GABARAPL1-6HIS fusion protein were treated with $1 \mu \mathrm{M}$ of 17-AAG with or without the specific proteasome inhibitor MG132 for $15 \mathrm{~h}$. The efficacy of treatment was first verified by immunodetection of the protein RIP1 in MCF-7 cells (Fig. 5A). The protein RIP1 is a well known HSP90 client protein as proved by disruption of the interaction between these two proteins following geldanamycin treatment. Moreover, geldanamycin-induced degradation of RIP1 was abrogated by MG132 treatment [34].

Similar results were obtained with the GABARAPL1 protein (Fig. 5B). Two signals were apparent in MCF-7-FLAG-GABARAPL16HIS cells in immunoblotting experiments using the antiGABARAPL1 antibody from Chemicon. The higher molecular weight band corresponded to FLAG-GABARAPL1-6HIS and the lowest one corresponded to GABARAP. Only one signal corresponding to FLAG-GABARAPL1-6HIS was detectable with the antiFLAG M2 antibody (Sigma-Aldrich) (data not shown). The endogenous GABARAPL1 protein is not usually apparent in immunoblot experiments performed on untreated MCF-7 and MCF-7-FLAGGABARAPL1-6HIS cells. 17-AAG treatment caused a marked decrease in the level of FLAG-GABARAPL1-6HIS protein compared with non-treated cells. The maximal effect of this compound in MCF-7-FLAG-GABARAPL1-6HIS cells is observed after $15 \mathrm{~h}$ of treatment (Fig. 5C). This result indicates that GABARAPL1 may be a client protein for active HSP90 since the molecular chaperoning activity of HSP90 appears to play an important role in the stability of GABARAPL1 in cells. We therefore hypothesized, that following treatment with 17-AAG, the interaction between the two proteins is abolished leading to FLAG-GABARAPL1-6HIS degradation by the proteasome. To confirm our hypothesis, we treated MCF-7-FLAGGABARAPL1-6HIS cells with the MG132 proteasome inhibitor. This treatment considerably enhanced the level of FLAG-GABARAPL1$6 \mathrm{HIS}$ in the cells. Interestingly, double treatment with 17-AAG and MG132 led to the same result, implying that proteasomal inhibition prevents the degradation of GABARAPL1 induced by 17AAG. As an aside, an additional signal, located between the bands corresponding to FLAG-GABARAPL1-6HIS and endogenous GABARAP, was observed in this experiment. We propose that this signal corresponds to the endogenous GABARAPL1 protein. The treatment of non-transfected MCF-7 cells with MG132 revealed this 


\section{A}

A Dsred-GABARAPL1
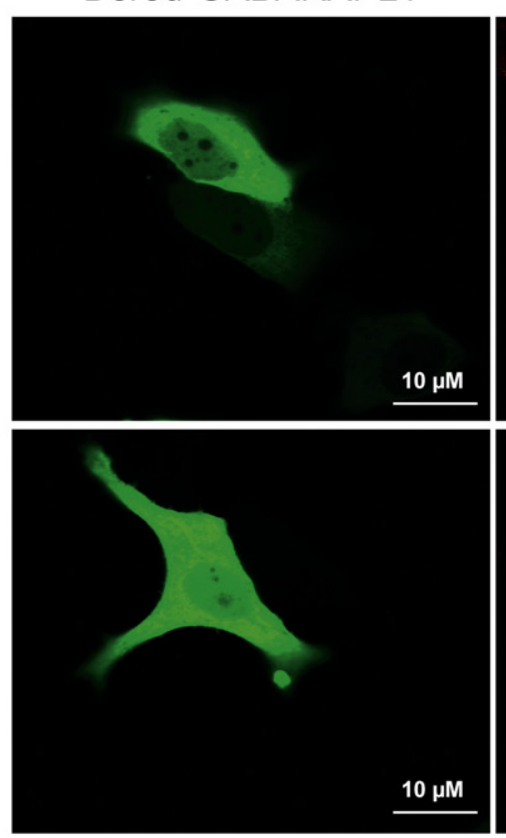

B
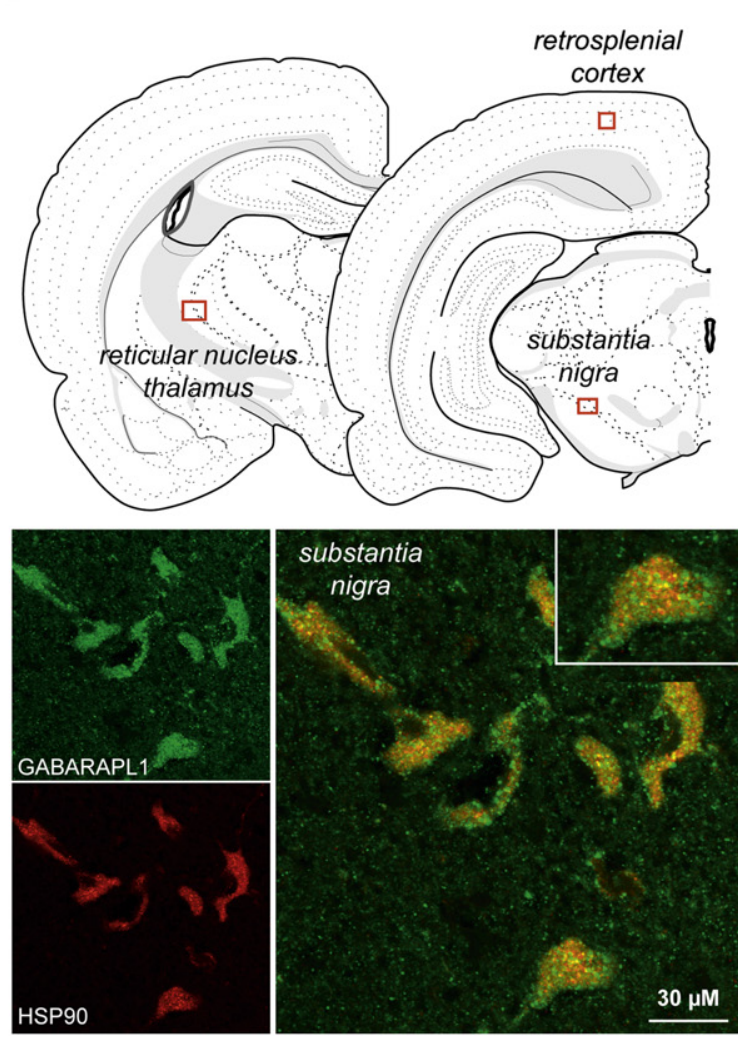

GFP-HSP90ß
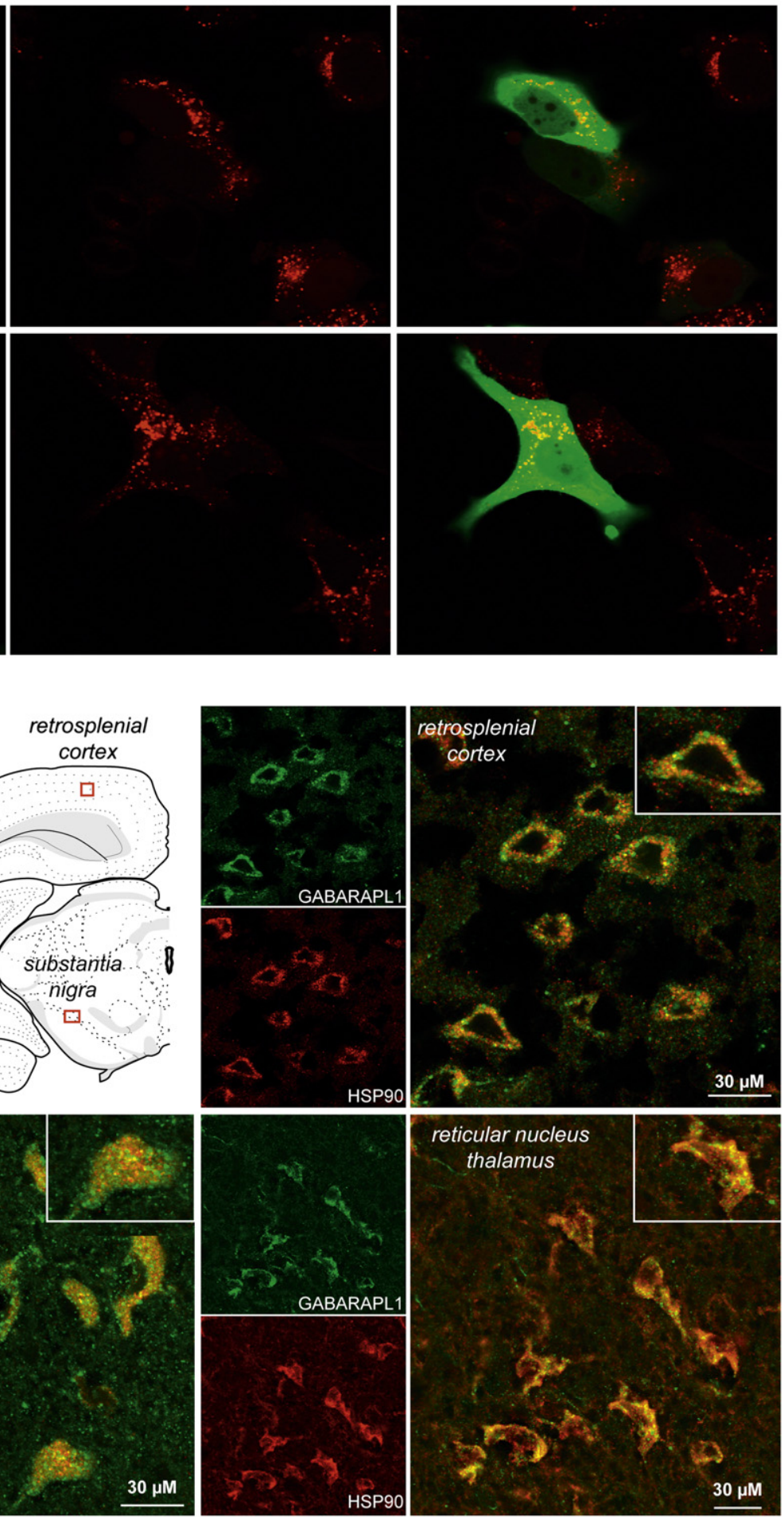

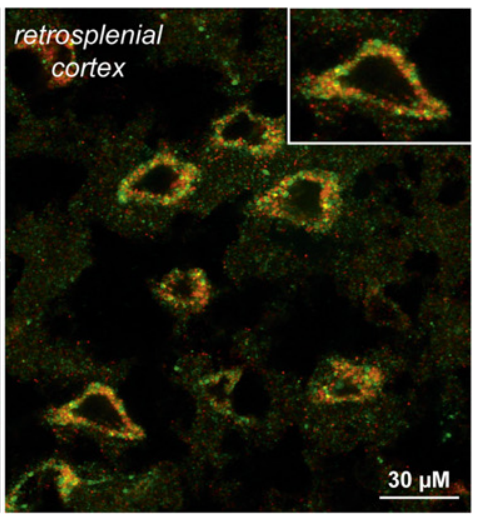

merge
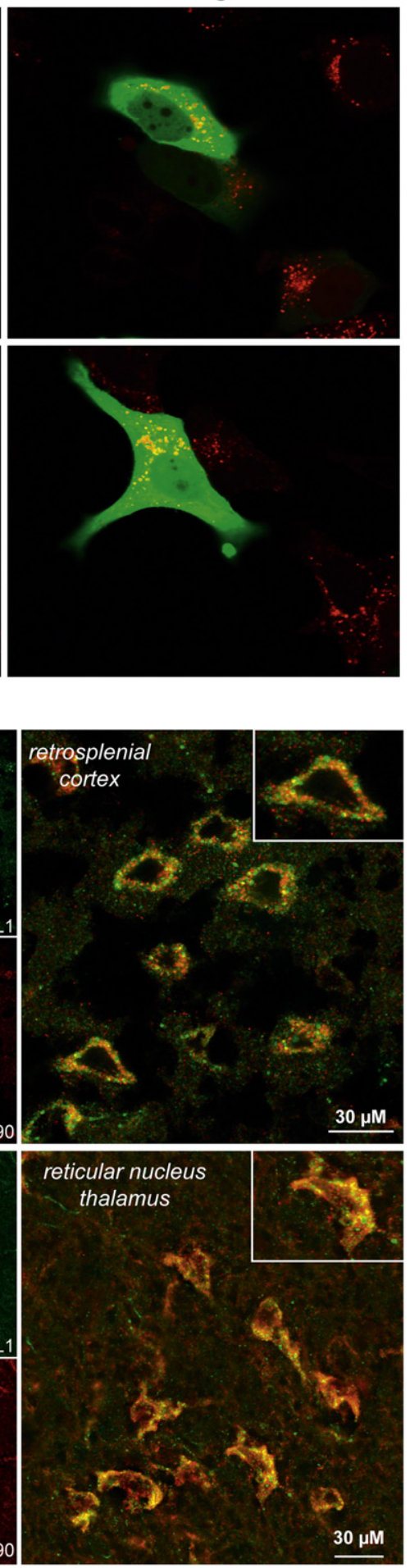

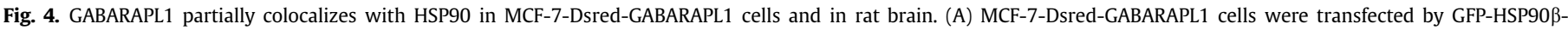

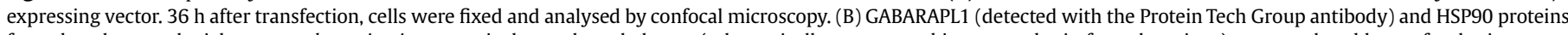

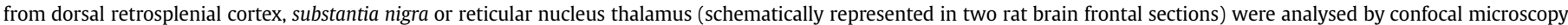

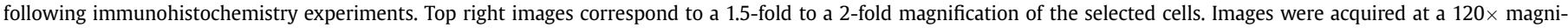

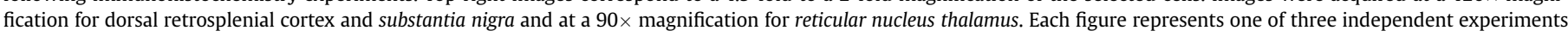
performed with similar results. 


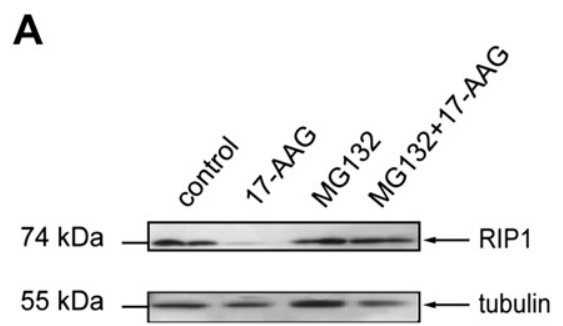

B

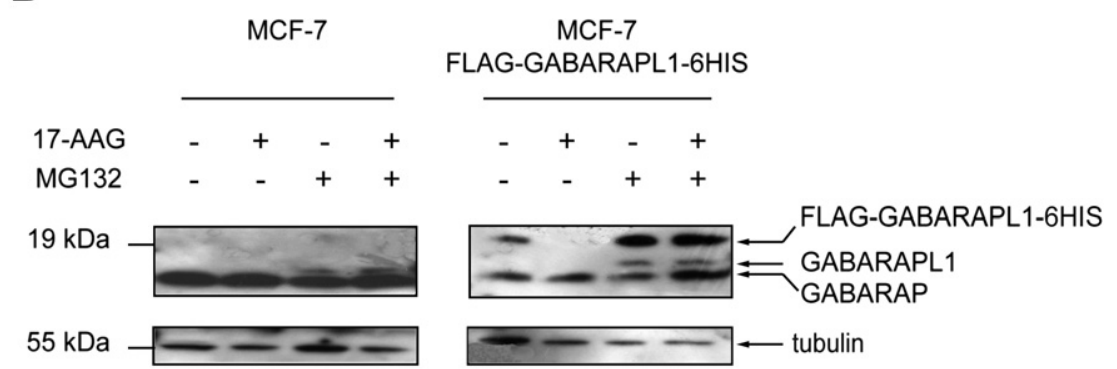

C

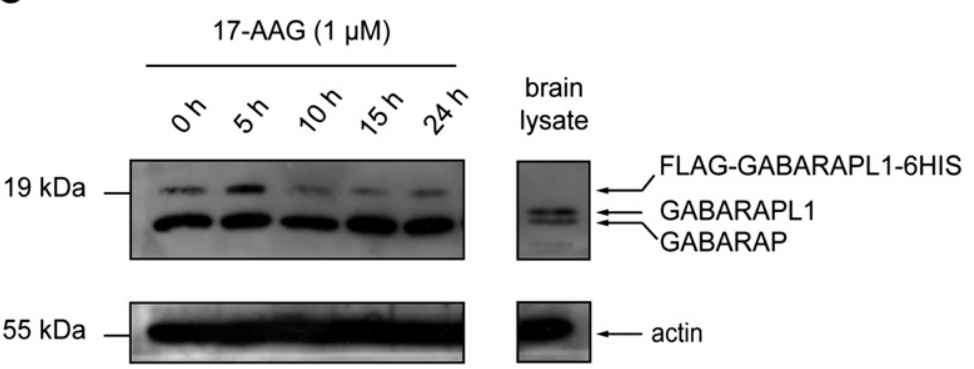

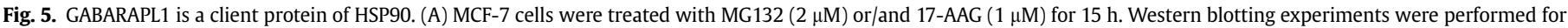

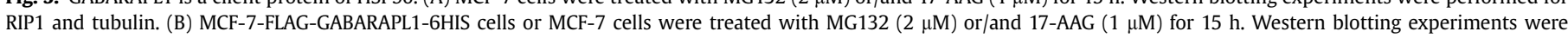

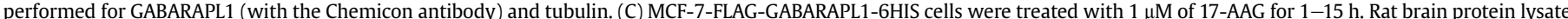

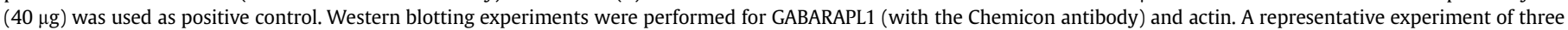
performed is shown.

same new signal, strongly suggesting the enhancement of endogenous GABARAPL1 protein levels, as well.

As shown in Fig. $6 \mathrm{~A}$ and $\mathrm{B}$, the MG132 effect is maximal at a concentration of $2 \mu \mathrm{M}$ and after $15 \mathrm{~h}$ of treatment. We then used two different proteasome inhibitors (lactacystin and bortezomib) to confirm that this effect is not due to side effects of MG132. As already observed in the MG132 experiments, treatment with either of these two chemicals resulted in an increased expression of FLAGGABARAPL1-6HIS and the apparition of a signal corresponding to endogenous GABARAPL1 (from $2.5 \mu \mathrm{M}$ of lactacystin and from $10 \mathrm{nM}$ of bortezomib) (Fig. 6C, D). We can thus confirm the expression of endogenous GABARAPL1 following proteasomal degradation blockade.

Interestingly, unlike GABARAPL1, no variation of GABARAP expression was observed with any of the proteasomal inhibitors tested, suggesting that these two highly related proteins are subjected to different post-translational regulation in cells under the conditions tested (Figs. 5 and 6).

Consequently, we can conclude that disruption of the chaperoning activity of HSP90 by 17-AAG causes the degradation of exogenous FLAG-GABARAPL1-6HIS and endogenous GABARAPL1 through the proteasome since the use of proteasome specific inhibitors leads to an accumulation of both the FLAG-GABARAPL16HIS and GABARAPL1 proteins in the cells.

Finally, we assessed effects of this disruption on the cellular localization and/or expression of Dsred-GABARAPL1 in MCF-7 cells by confocal microscopy (Fig. 7). Similar to the results obtained by Western blot, 17-AAG treatment led to the reduction of DsredGABARAPL1 staining, whereas an opposite effect was observed when cells were stimulated with MG132 and 17-AAG combined with MG132.

\section{Discussion}

In this study, a GST pull-down assay followed by mass spectrometry analysis led to the discovery of various new GABARAPL1 partners, opening the door to new functional investigations for this protein. Among these partners, we identified HSP90 $\beta$ as a new GABARAPL1-interacting protein. We also confirmed previously published GABARAPL1 and/or GABARAP protein-interactions. For example, we found the clathrin heavy chain protein, a GABARAP cellular partner that is essential in the formation of coated vesicles [25]. In the brain, neurons regulate the number of postsynaptic receptors, such as $\mathrm{GABA}_{\mathrm{A}}$ receptors, by internalization in clathrincoated vesicles. Amongst identified proteins in mass spectrometry analysis, we also found the AP-2 (adaptor protein-2) and dynamin (D100) proteins which are known to take part in $\mathrm{GABA}_{\mathrm{A}}$ receptors endocytosis [35,36]. Consequently, GABARAPL1 may associate with these three proteins to aid in the turnover of $G_{A B A}$ receptors. Subunits of tubulin were also identified, reinforcing the hypothesis that GABARAPL1 mediates intracellular trafficking of proteins, such as $\mathrm{GABA}_{A}$ or k-opioid receptors, in the brain $[8,9,11]$. 
A

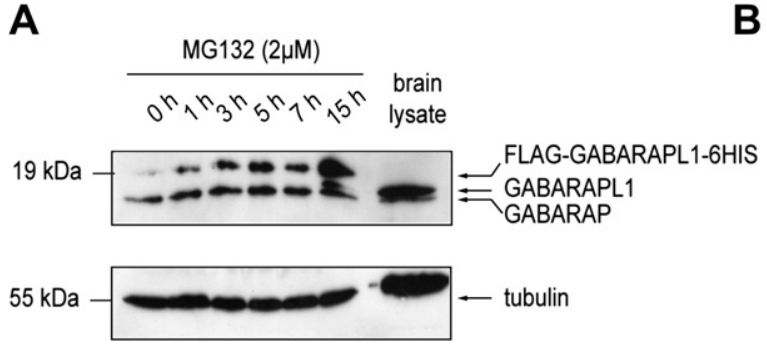

B

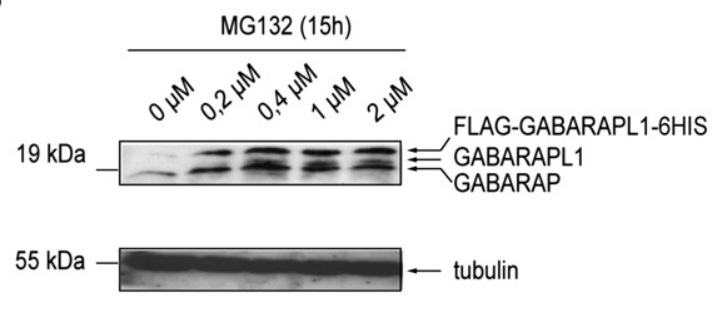

C

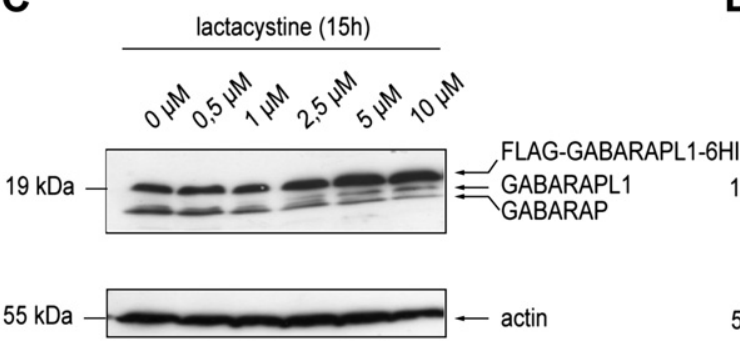

D

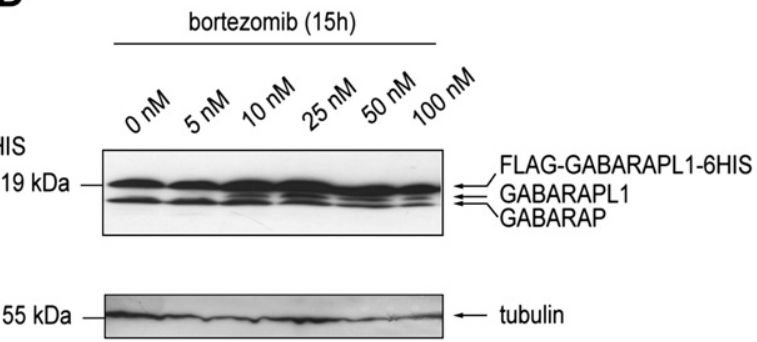

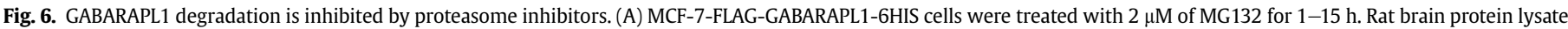

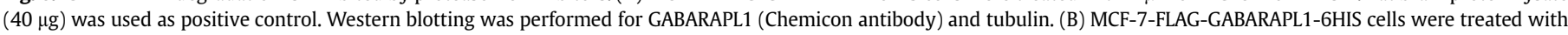

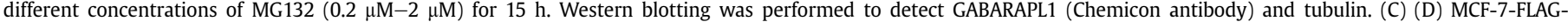

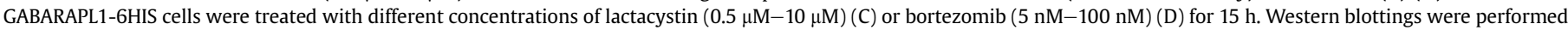
for GABARAPL1 (Chemicon antibody), tubulin and actin. Each figure represents one of three independent experiments performed with similar results.

We then focused our attention on the potential new GABARAPL1-interacting partner HSP90 $\beta$ because of its involvement in various cellular processes including cell proliferation, differentiation and apoptosis [37]. HSP90 is a highly conserved and abundant protein in eukaryotic cells, corresponding to $1-2 \%$ of total cellular proteins under non-stress conditions [26]. There are two major cytoplasmic isoforms of HSP90, HSP90 $\alpha$ and HSP90 $\beta$, which share approximately $86 \%$ identity in vertebrate species [38]. HSP90 is a molecular chaperone that interacts with multiple co-chaperones to assure the maintenance of protein quality in the cell by regulating the balance between folding and degradation of proteins. A growing list of HSP90 client proteins, which now includes several hundreds of proteins, is currently maintained by the laboratory of Didier Picard [39]. HSP90 client proteins include a variety of transcription factors such as mutated p53, protein kinases (Akt, ErbB2, Raf, RIP1), cell surface receptors and cellular enzymes. The $\mathrm{NH}_{2}$ terminal ATP/ADP binding pocket of HSP90 is important for its folding function as a chaperone. Moreover, this domain is the binding site of specific drugs including ansamycin antibiotics such as geldanamycin and its modified derivative 17-AAG [40]. These drugs competitively inhibit ATP binding and induce a conformational change in the HSP90 molecule that results in a destabilization of its interaction with its chaperoned proteins and their subsequent degradation through the proteasome pathway [41]. These drugs also display antitumor activity in numerous animal tumor models and their effects are currently being evaluated in several clinical trials [33,42-44].

In this work, we demonstrate that GABARAPL1 interacts directly with both HSP90 $\alpha$ and $\beta$ isoforms as demonstrated by use of either purified GST-HSP90 $\alpha$ or HSP90 $\beta$ proteins in GST pull-down assays and by use of an antibody directed against the two isoforms in coimmunoprecipitation experiments. In the immunoprecipitation experiment performed using rat brain extracts, an antibody directed against GABARAPL1 versus GABARAP was used to immunoprecipitate GABARAPL1 and an antibody recognizing the two proteins was used in immunoblot. In the brain, the GABARAP protein, although to a lesser extent than GABARAPL1, was immunoprecipitated disallowing us to exclude the possibility of an untreated

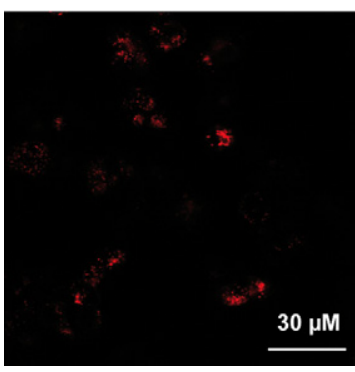

17-AAG

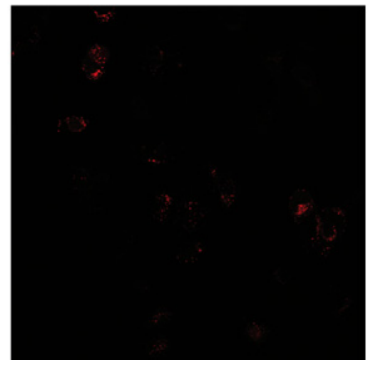

MG132

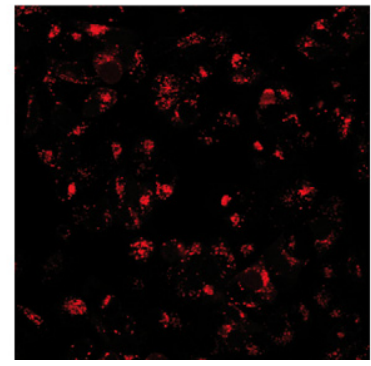

17-AAG+MG132

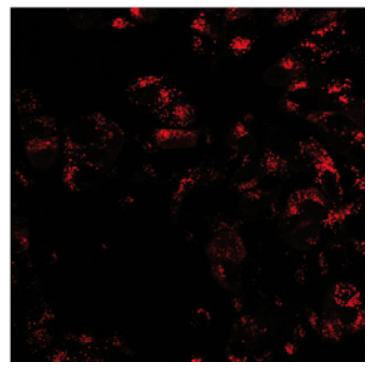

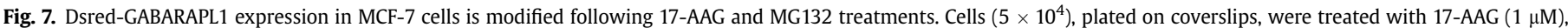

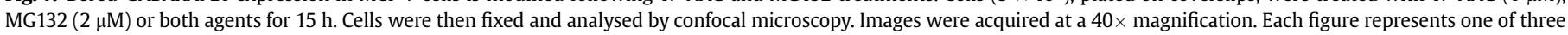
independent experiments performed with similar results. 
interaction between GABARAP and HSP90 or between GABARAPL1 and GABARAP. However, in the MCF-7-FLAG-GABARAPL1-6HIS cellular model, the specific interaction between GABARAPL1 and HSP90 is confirmed with the use of an anti-FLAG antibody, which specifically immunoprecipitates GABARAPL1. Moreover, the interaction between GABARAP or GATE-16 and HSP90 $\beta$ was confirmed by in vitro pull-down experiments and was also observed by Behrends et al. in HEK293 cells [30]. This same study revealed, on one hand, a potential interaction between HSP90 $\alpha$ and/or $\beta$ isoforms and all other Atg8 family members, GATE-16, LC3A, LC3B and LC3C and on the other hand, the interaction between GABARAPL1 and other HSP proteins such as HSP70, HSP60 and HSP105.

Mansuy et al. previously demonstrated that the first 22 aminoterminal residues of GABARAPL1 are implicated in tubulin binding [8]. Here, we show that the presence of this basic $\mathrm{N}$-terminal region (pHi 9.6) allows for a stronger interaction between GABARAPL1 and the acidic HSP90 protein (pHi 5). Distribution of both GABARAPL1 and HSP90 proteins was analysed in MCF-7 stably expressing Dsred-GABARAPL1 and in three rat brain regions known to express high levels of gabarapl1 mRNA (retrosplenial cortex, substantia nigra and reticular nucleus thalamus). Experiments performed in MCF-7-Dsred-GABARAPL1 cells revealed a partial colocalization of Dsred-GABARAPL1 and GFP-HSP90 $\beta$ in intracytoplasmic perinuclear dots. A similar partial colocalization was found in the two rat brain regions studied by immunohistochemistry.

The role of the association between GABARAPL1 and HSP90 was established by the use of the HSP90 activity specific inhibitor 17AAG. Following disruption of the interaction between the two proteins, the degradation of GABARAPL1 was demonstrated to be mediated by the proteasome as established by the use of various potent proteasome inhibitors. Interestingly, unlike GABARAPL1, GABARAP protein levels were not affected by the different treatments despite the fact that GABARAP might interact with HSP90, highlighting a major difference in the regulation of these two closely related homologues. We have demonstrated, using quantitative RT-PCR experiments an increase of the endogenous gabarapl1 mRNA level in MCF-7 cells treated by MG132 (data not shown). Moreover, gene profiling studies of prostate cancer cells treated with MG132 and pancreatic cancer cells treated with bortezomib revealed an up-regulation of gabarapl1 and $l c 3$ mRNA $[45,46]$. However, in our MCF-7-FLAG-GABARAPL1-6HIS model, the rate of synthesis of the fusion protein increases independently of the transcriptional activation. On the other hand, the increase of the endogenous GABARAPL1 protein level is due to a regulation of its stability associated with a transcriptional regulation of the gabarapl1 gene. Recent studies have demonstrated that inhibition of proteasomal degradation by specific inhibitors induces autophagy, identified by accumulation of LC3B-II, the lipidated form of LC3B that localizes to autophagosomes [47-49]. It is now obvious that these two major routes of degradation are intimately linked. In particular, impairment of degradation by the proteasome pathway causes induction of autophagy [50]. Surprisingly, no presence of the GABARAPL1-II form, already observed in cells by Chakrama et al. in autophagic conditions [17], is detectable in our experiments, suggesting that GABARAPL1 is not associated to autophagic vesicles following the inhibition of proteasomal activity. These observations therefore describe a differential regulation of GABARAPL1 and LC3B in presence of proteasome inhibitors.

Generally, prior ubiquitinylation of the majority of HSP90 client proteins is required for them to be recognized and subsequently delivered to the proteasome. Some oncosuppressive client proteins, however, such as p53, display a ubiquitin-independent degradation by the proteasome [51]. Preliminary results show that GABARAPL1 is not ubiquitinylated as shown for LC3B (data not shown). Indeed, LC3B can be processed by the $20 \mathrm{~S}$ core proteasome in a ubiquitin- independent manner in vitro and this degradation is inhibited by its interaction with p62, a mediator of autophagic proteolysis [52]. Concerning GABARAP, Chen et al. suggest that GABARAP does not undergo the ubiquitinylation process and is not degraded through the proteasome after lactacystin treatment in rat cultured hippocampal neurons [53].

In this report, we successfully screened for novel GABARAPL1 binding partners by performing a simple pull-down assay coupled to mass spectrometry, demonstrating that GABARAPL1 associates with the HSP90 protein and providing evidence for a direct interaction between these two proteins. This study shows, for the first time, that HSP90 protects GABARAPL1 from its proteasomal degradation and therefore increases its stability in MCF-7 cells. These findings provide new and interesting information about the GABARAPL1 turnover within the cell.

\section{Acknowledgements}

We are grateful to Dr. Altieri, Dr. J. Kim and Dr. Elazar for kindly providing the pGST-HSP90 $\alpha$, the pGFP-HSP90 $\beta$ and the pGEX-4-T2 GST-GATE-16 vectors respectively. We would like to thank Fabrice Poncet, Sophie Launay (Plateformes microscopie et séquençage, IFR133, Besançon), Valérie Perez and Elodie Bôle-Richard for their technical help.

This work was supported by a grant from Ligue Contre le Cancer (Conférence de Coordination InterRégionale-Grand Est), Comité du Doubs. Stéphanie Seguin-Py is supported by a fellowship from Région de Franche-Comté/Cancéropôle Grand-Est. Sophie Croizier, Fatima Zahra Chakrama and Jaclyn Nicole Le Grand are supported by fellowships from the Ministère de l'Enseignement Supérieur et de la Recherche (MESR).

\section{References}

[1] I. Pellerin, C. Vuillermoz, M. Jouvenot, C. Ordener, M. Royez, G.L. Adessi, Identification and characterization of an early estrogen-regulated RNA in cultured guinea-pig endometrial cells, Mol. Cell. Endocrinol. 90 (1993) $\mathrm{R} 17-\mathrm{R} 21$.

[2] N. Le Grand, F.Z. Chakrama, S. Seguin-Py, A. Fraichard, R. Delage-Mourroux, M. Jouvenot, M. Boyer-Guittaut, GABARAPL1 (GEC1): original or copycat? Autophagy 7 (2011) 1302-1307.

[3] Y. Paz, Z. Elazar, D. Fass, Structure of GATE-16, membrane transport modulator and mammalian ortholog of autophagocytosis factor Aut7p, J. Biol. Chem. 275 (2000) 25445-25450.

[4] Y. Sagiv, A. Legesse-Miller, A. Porat, Z. Elazar, GATE-16, a membrane transport modulator, interacts with NSF and the Golgi v-SNARE GOS-28, Embo J. 19 (2000) 1494-1504

[5] Y. Xin, L. Yu, Z. Chen, L. Zheng, Q. Fu, J. Jiang, P. Zhang, R. Gong, S. Zhao, Cloning, expression patterns, and chromosome localization of three human and two mouse homologues of $\operatorname{GABA}(\mathrm{A})$ receptor-associated protein, Genomics 74 (2001) 408-413.

[6] V. Mansuy-Schlick, F. Tolle, R. Delage-Mourroux, A. Fraichard, P.Y. Risold, M. Jouvenot, Specific distribution of gabarap, gec1/gabarap Like 1, gate16/ gabarap Like 2, lc3 messenger RNAs in rat brain areas by quantitative realtime PCR, Brain Res. 1073-1074 (2006) 83-87.

[7] F. Tolle, P. Risold, V. Mansuy-Schlick E. Rossi, M. Boyer-Guittaut, A. Fraichard, M. Jouvenot, Specific regional distribution of gec1 mRNAs in adult rat central nervous system, Brain Res. 1210 (2008) 103-115.

[8] V. Mansuy, W. Boireau, A. Fraichard, J.L. Schlick, M. Jouvenot, R. DelageMourroux, GEC1, a protein related to GABARAP, interacts with tubulin and GABA(A) receptor, Biochem. Biophys. Res. Commun. 325 (2004) 639-648.

[9] C. Chen, J.G. Li, Y. Chen, P. Huang, Y. Wang, L.Y. Liu-Chen, GEC1 interacts with the kappa opioid receptor and enhances expression of the receptor, J. Biol. Chem. 281 (2006) 7983-7993.

[10] Y. Chen, C. Chen, E. Kotsikorou, D.L. Lynch, P.H. Reggio, L.Y. Liu-Chen, GEC1kappa opioid receptor binding involves hydrophobic interactions: GEC1 has chaperone-like effect, J. Biol. Chem. 284 (2009) 1673-1685.

[11] C. Chen, Y. Wang, P. Huang, L.Y. Liu-Chen, Effects of C-terminal modifications of GEC1 and GABARAP, two microtubules-associated proteins, on kappa opioid receptor expression, J. Biol. Chem. 286 (2011) 15106-15115.

[12] T. Nakamura, T. Hayashi, Y. Nasu-Nishimura, F. Sakaue, Y. Morishita, T. Okabe, S. Ohwada, K. Matsuura, T. Akiyama, PX-RICS mediates ER-to-Golgi transport of the N-cadherin/beta-catenin complex, Genes Dev. 22 (2008) 1244-1256. 
[13] C. Schnack, K.M. Danzer, B. Hengerer, F. Gillardon, Protein array analysis of oligomerization-induced changes in alpha-synuclein protein-protein interactions points to an interference with Cdc42 effector proteins, Neuroscience 154 (2008) 1450-1457.

[14] M.G. Mameza, J.M. Lockard, E. Zamora, M. Hillefors, Z.S. Lavina, B.B. Kaplan, Characterization of the adaptor protein ARH expression in the brain and ARH molecular interactions, J. Neurochem. 103 (2007) 927-941.

[15] C. Nemos, V. Mansuy, S. Vernier-Magnin, A. Fraichard, M. Jouvenot, R. DelageMourroux, Expression of gec1/GABARAPL1 versus GABARAP mRNAs in human: predominance of gec1/GABARAPL1 in the central nervous system, Brain Res. Mol. Brain Res. 119 (2003) 216-219.

[16] A. Berthier, S. Seguin, A.J. Sasco, J.Y. Bobin, G. De Laroche, J. Datchary, S. Saez, C. Rodriguez-Lafrasse, F. Tolle, A. Fraichard, M. Boyer-Guittaut, M. Jouvenot, R. Delage-Mourroux, F. Descotes, High expression of gabarapl1 is associated with a better outcome for patients with lymph node-positive breast cancer, Br. J. Cancer 102 (2010) 1024-1031.

[17] F.Z. Chakrama, S. Seguin-Py, J.N. Le Grand, A. Fraichard, R. Delage-Mourroux, G. Despouy, V. Perez, M. Jouvenot, M. Boyer-Guittaut, GABARAPL1 (GEC1) associates with autophagic vesicles, Autophagy 6 (2010) 1-11.

[18] V.M. Betin, J.D. Lane, Caspase cleavage of Atg4D stimulates GABARAP-L1 processing and triggers mitochondrial targeting and apoptosis, J. Cell. Sci. 122 (2009) 2554-2566.

[19] S. Pankiv, T.H. Clausen, T. Lamark, A. Brech, JA. Bruun, H. Outzen, A Overvatn, G. Bjorkoy, T. Johansen, p62/SQSTM1 binds directly to Atg8/LC3 to facilitate degradation of ubiquitinated protein aggregates by autophagy, J. Biol. Chem. 282 (2007) 24131-24145

[20] K.B. Larsen, T. Lamark, A. Overvatn, I. Harneshaug, T. Johansen, G. Bjorkoy, A reporter cell system to monitor autophagy based on p62/SQSTM1, Autophagy 6 (2010) 784-793.

[21] J.F. Rual, K. Venkatesan, T. Hao, T. Hirozane-Kishikawa, A. Dricot, N. Li, G.F. Berriz, F.D. Gibbons, M. Dreze, N. Ayivi-Guedehoussou, N. Klitgord, C. Simon, M. Boxem, S. Milstein, J. Rosenberg, D.S. Goldberg, L.V. Zhang, S.L. Wong, G. Franklin, S. Li, J.S. Albala, J. Lim, C. Fraughton, E. Llamosas, S. Cevik, C. Bex, P. Lamesch, R.S. Sikorski, J. Vandenhaute, H.Y. Zoghbi, A. Smolyar, S. Bosak, R. Sequerra, L. Doucette-Stamm, M.E. Cusick, D.E. Hill, F.P. Roth, M. Vidal, Towards a proteome-scale map of the human proteinprotein interaction network, Nature 437 (2005) 1173-1178.

[22] I. Novak, V. Kirkin, D.G. McEwan, J. Zhang, P. Wild, A. Rozenknop, V. Rogov, F. Lohr, D. Popovic, A. Occhipinti, A.S. Reichert, J. Terzic, V. Dotsch, P.A. Ney, I. Dikic, Nix is a selective autophagy receptor for mitochondrial clearance, EMBO Rep. 11 (2010) 45-51.

[23] F. Brischoux, D. Fellmann, P.Y. Risold, Ontogenetic development of the diencephalic MCH neurons: a hypothalamic 'MCH area' hypothesis, Eur. J. Neurosci. 13 (2001) 1733-1744.

[24] P.M. Schenk, S. Baumann, R. Mattes, H.H. Steinbiss, Improved high-level expression system for eukaryotic genes in Escherichia coli using T7 RNA polymerase and rare ArgtRNAs, Biotechniques 19 (1995) 196-198 200

[25] J. Mohrluder, Y. Hoffmann, T. Stangler, K. Hanel, D. Willbold, Identification of clathrin heavy chain as a direct interaction partner for the gammaaminobutyric acid type A receptor associated protein, Biochemistry 46 (2007) 14537-14543.

[26] D. Picard, Heat-shock protein 90, a chaperone for folding and regulation, Cell. Mol. Life Sci. 59 (2002) 1640-1648.

[27] R. Zhao, M. Davey, Y.C. Hsu, P. Kaplanek, A. Tong, A.B. Parsons, N. Krogan, G. Cagney, D. Mai, J. Greenblatt, C. Boone, A. Emili, W.A. Houry, Navigating the chaperone network: an integrative map of physical and genetic interactions mediated by the hsp90 chaperone, Cell 120 (2005) 715-727.

[28] A. Gimenez Ortiz, J. Montalar Salcedo, Heat shock proteins as targets in oncology, Clin. Transl. Oncol. 12 (2010) 166-173.

[29] P. Gass, H. Schroder, P. Prior, M. Kiessling, Constitutive expression of heat shock protein 90 (HSP90) in neurons of the rat brain, Neurosci. Lett. 182 (1994) 188-192.

[30] C. Behrends, M.E. Sowa, S.P. Gygi, J.W. Harper, Network organization of the human autophagy system, Nature 466 (2010) 68-76.

[31] F. Chiacchiera, A. Matrone, E. Ferrari, G. Ingravallo, G. Lo Sasso, S. Murzilli, M. Petruzzelli, L. Salvatore, A. Moschetta, C. Simone, p38alpha blockade inhibits colorectal cancer growth in vivo by inducing a switch from HIF1alpha- to FoxO-dependent transcription, Cell Death Differ. 16 (2009) 1203-1214.

[32] B.S. Blagg, T.D. Kerr, Hsp90 inhibitors: small molecules that transform the Hsp90 protein folding machinery into a catalyst for protein degradation, Med. Res. Rev. 26 (2006) 310-338.

[33] L. Neckers, Hsp90 inhibitors as novel cancer chemotherapeutic agents, Trends Mol. Med. 8 (2002) S55-S61.

[34] J. Lewis, A. Devin, A. Miller, Y. Lin, Y. Rodriguez, L. Neckers, Z.G. Liu, Disruption of hsp90 function results in degradation of the death domain kinase, receptorinteracting protein (RIP), and blockage of tumor necrosis factor-induced nuclear factor-kappaB activation, J. Biol. Chem. 275 (2000) 10519-10526.

[35] J.T. Kittler, P. Delmas, J.N. Jovanovic, D.A. Brown, T.G. Smart, S.J. Moss, Constitutive endocytosis of GABAA receptors by an association with the adaptin AP2 complex modulates inhibitory synaptic currents in hippocampal neurons, J. Neurosci. 20 (2000) 7972-7977.

[36] D. Herring, R. Huang, M. Singh, L.C. Robinson, G.H. Dillon, N.J. Leidenheimer Constitutive GABAA receptor endocytosis is dynamin-mediated and dependent on a dileucine AP2 adaptin-binding motif within the beta 2 subunit of the receptor, J. Biol. Chem. 278 (2003) 24046-24052.

[37] A.S. Sreedhar, E. Kalmar, P. Csermely, Y.F. Shen, Hsp90 isoforms: functions, expression and clinical importance, FEBS Lett. 562 (2004) 11-15.

[38] R.S. Gupta, Phylogenetic analysis of the $90 \mathrm{kD}$ heat shock family of protein sequences and an examination of the relationship among animals, plants, and fungi species, Mol. Biol. Evol. 12 (1995) 1063-1073.

[39] P.C. Echeverría, A. Bernthaler, P. Dupuis, B. Mayer, D. Picard, An interaction network Predicted from Public data as a discovery Tool: application to the Hsp90 molecular chaperone Machine, PLoS One 6 (2011) e26044.

[40] C. Prodromou, S.M. Roe, R. O’Brien, J.E. Ladbury, P.W. Piper, L.H. Pearl, Identification and structural characterization of the ATP/ADP-binding site in the Hsp90 molecular chaperone, Cell 90 (1997) 65-75.

[41] S. Sharp, P. Workman, Inhibitors of the HSP90 molecular chaperone: current status, Adv. Cancer Res. 95 (2006) 323-348.

[42] M.P. Goetz, D.O. Toft, M.M. Ames, C. Erlichman, The Hsp90 chaperone complex as a novel target for cancer therapy, Ann. Oncol. 14 (2003) 1169-1176.

[43] S.Z. Usmani, R. Bona, Z. Li, 17 AAG for HSP90 inhibition in cancer-from bench to bedside, Curr. Mol. Med. 9 (2009) 654-664.

[44] U. Banerji, Heat shock protein 90 as a drug target: some like it hot, Clin. Cancer Res. 15 (2009) 9-14.

[45] W. Yang, J. Monroe, Y. Zhang, D. George, E. Bremer, H. Li, Proteasome inhibition induces both pro- and anti-cell death pathways in prostate cancer cells, Cancer Lett. 243 (2006) 217-227.

[46] Z.Y. Tang, Y.L. Wu, S.L. Gao, H.W. Shen, Effects of the proteasome inhibitor bortezomib on gene expression profiles of pancreatic cancer cells, J. Surg. Res. 145 (2008) 111-123.

[47] W.K. Wu, Y.C. Wu, L. Yu, Z.J. Li, J.J. Sung, C.H. Cho, Induction of autophagy by proteasome inhibitor is associated with proliferative arrest in colon cance cells, Biochem. Biophys. Res. Commun. 374 (2008) 258-263.

[48] W.X. Ding, H.M. Ni, W. Gao, T. Yoshimori, D.B. Stolz, D. Ron, X.M. Yin, Linking of autophagy to ubiquitin-proteasome system is important for the regulation of endoplasmic reticulum stress and cell viability, Am. J. Pathol. 171 (2007) 513-524.

[49] M. Milani, T. Rzymski, H.R. Mellor, L. Pike, A. Bottini, D. Generali, A.L. Harris The role of ATF4 stabilization and autophagy in resistance of breast cancer cells treated with Bortezomib, Cancer Res. 69 (2009) 4415-4423.

[50] V.I. Korolchuk, F.M. Menzies, D.C. Rubinsztein, A novel link between autophagy and the ubiquitin-proteasome system, Autophagy 5 (2009) 862-863.

[51] I. Jariel-Encontre, G. Bossis, M. Piechaczyk, Ubiquitin-independent degradation of proteins by the proteasome, Biochim. Biophys. Acta 1786 (2008) $153-177$.

[52] Z. Gao, N. Gammoh, P.M. Wong, H. Erdjument-Bromage, P. Tempst, X. Jiang, Processing of autophagic protein LC3 by the 20S proteasome, Autophagy 6 (2010) 126-137.

[53] Z.W. Chen, C.S. Chang, T.A. Leil, R.W. Olsen, C-terminal modification is required for GABARAP-mediated GABA(A) receptor trafficking, J. Neurosci. 27 (2007) 6655-6663. 